\title{
A systematic review of interventions to provide genetics education for primary care
}

Milena Paneque ${ }^{1,2}$, Daniela Turchetti ${ }^{3}$, Leigh Jackson ${ }^{4}$, Peter Lunt ${ }^{4}$, Elisa Houwink ${ }^{5,6}$ and Heather Skirton ${ }^{4^{*}}$

\begin{abstract}
Background: At least $10 \%$ of patients seen in primary care are said to have a condition in which genetics has an influence. However, patients at risk of genetic disease may not be recognised, while those who seek advice may not be referred or managed appropriately. Primary care practitioners lack knowledge of genetics and genetic testing relevant for daily practice and feel inadequate to deliver genetic services. The aim of this systematic review was to evaluate genetics educational interventions in the context of primary care.

Methods: Following the process for systematic reviews developed by the Centre for Reviews and Dissemination, we conducted a search of five relevant electronic databases. Primary research papers were eligible for inclusion if they included data on outcomes of interventions regarding genetics education for primary care practitioners. The results from each paper were coded and grouped under themes.
\end{abstract}

Results: Eleven studies were included in the review. The five major themes identified inductively (post hoc) were: prior experience, changes in confidence, changes in knowledge, changes in practice, satisfaction and feedback. In five of the studies, knowledge of practitioners was improved following the educational programmes, but this tended to be in specific topic areas, while practitioner confidence improved in six studies. However, there was little apparent change to practice.

Conclusions: There are insufficient studies of relevant quality to inform educational interventions in genetics for primary care practitioners. Educational initiatives should be assessed using changes in practice, as well as in confidence and knowledge, to determine if they are effective in causing significant changes in practice in genetic risk assessment and appropriate management of patients.

Keywords: Genetics, Professional education, Systematic review, Primary care

\section{Background}

It is estimated that approximately $10 \%$ of United States (US) citizens [1] and $6 \%$ of Europeans [2] are affected by a rare disease, equating to approximately 30 million individuals in the US [1] and the same number in Europe [2]. Of all rare diseases, $80 \%$ have a genetic component [2] and it is therefore not surprising that at least $10 \%$ of patients seen in the primary care setting are said to have a condition in which genetics has an influence [3]. However, there is evidence that patients at risk of genetic disease may not be recognised, while those who seek advice about their risks of rare genetic diseases may not be referred or managed appropriately

\footnotetext{
* Correspondence: Heather.skirton@plymouth.ac.uk

${ }^{4}$ Faculty of Health and Human Sciences, Plymouth University, Plymouth PL4 8AA, UK

Full list of author information is available at the end of the article
}

by health professionals [4]. This may relate to lack of awareness of the family that a condition may have a genetic component, or may be due to lack of knowledge in primary care professionals that this may be so. A Dutch study in 2003 [5] showed that $70 \%$ of patients believed that general practitioners (GPs) were not competent to handle queries about rare genetic conditions adequately, while in the US similar concerns about the competence of primary care practitioners to manage the patients with genetic concerns appropriately have been raised [6]. Undetected genetic risk can have serious consequences for the entire family, for example through preventing access to screening or preventive drugs or surgery (e.g. for cancer), resulting in increased morbidity, mortality, family burden and healthcare costs. Raising awareness of 
the risks and potential management of such cases is important for the patient and the wider family.

In the age of genomics, primary care practitioners will be increasingly involved in preventive care and organisation of relevant surveillance and develop a more flexible way to deal with patients' requests for information and genetic tests. Primary care can be provided by a range of health professionals and is defined by the World Health Organisation as health care that is directly accessible by patients as the first point of contact, as well as being comprehensive and ongoing [7]. It involves prevention, and pre-symptomatic detection of disease, as well as early diagnosis [7], all of which are relevant to patients at risk of genetic disease. To illustrate this, Acheson et al. [8] reported that a sample of 100 primary care physicians had faced questions from patients related to familial cancer, neurological conditions, prenatal testing issues and a wide range of single gene disorders, confirming the need for knowledge and skill to deal with such queries. However, it has been reported that primary care physicians lack knowledge of genetics relevant for daily practice, lack oversight of genetic testing and feel inadequate to deliver genetic services $[6,9,10]$.

As a result of a Delphi study involving experts in primary care education and genetic specialists in the United Kingdom (UK), Burke et al. [11] identified that primary care practitioners had three main responsibilities in relation to genetics: being able to identify patients at risk of a condition, contributing to medical management of such patients and appropriate communication of genetic information to patients. The authors of the paper developed a curriculum for genetics education in primary care organised according to these three activities [11]. However, genetics education is only very slowly starting to become a common part of medical curricula. This was made evident in a study by Julien-Reynier et al. [12], who studied the educational needs of 1170 GPs in five European countries and found that priorities for education differed according to country, gender and age of the physician. An average of $23.5 \%$ (range 4.7$42 \%)$ had received no genetics education in their undergraduate medical training, while another $29.7 \%$ reported that the education they had received was not useful to them in their practice. A total of $984(85.1 \%)$ had not undertaken any continuing medical education related to genetics. Overall, the highest priority for education was 'Genetics of Common Diseases', followed by 'Approaching Genetic Risk Assessment in Clinical Practice,' 'Psychosocial and Counseling Issues', 'Basic Genetics and Congenital Malformations,' 'Ethical, Legal and Public Health Issues' and lastly 'Techniques and Innovation in Genetics'.

However, provision of education may not always be sufficient to ensure improvements in patient care. In a paper on utilisation of research in practice, Grol and
Grimshaw [13] point out that while many health professionals undertake continuing medical education, it is difficult to link this with changes in practice. This is borne out by Weinreich et al. [14], who instituted an educational programme focussed on improving detection of patients at risk of haemoglobinopathy, but found that while GPs regarded the education positively, this was not converted into changes in screening based on the patient's ethnicity.

It is therefore clear that continuing medical education that is grounded in daily practice of GPs is urgently needed [9]. In order to provide effective genetics education, knowledge of the interventions that have been used in the past, and the outcomes of those interventions with their potential impact on health, is required. The aim of this study was to conduct a systematic review of educational interventions focussed on genetics and used in the context of primary care. The specific research question was: What are the outcomes of educational interventions in genetics for primary care professionals? As this was a mixed methods review, we used an inductive approach to search for possible outcomes. However, we anticipated that in line with the educational assessment framework proposed by Kirkpatrick [15] that is described later in this paper, outcomes would include satisfaction, changes in knowledge and skills and changes in behaviour.

\section{Methods}

Conducting a systematic review enables the evidence on a particular topic to be gathered, analysed and synthesised. Adherence to a rigorous set of guidelines is essential to ensure rigour and objectivity. We followed the process for systematic reviews developed by the Centre for Reviews and Dissemination [16], which involved identification of relevant search terms, selection of studies based on explicit inclusion and exclusion criteria and quality assessment of papers (Table 1). The software package EndnoteX7 [17] was used to store, organise and retrieve all citations during the review process.

\section{Search strategy}

We conducted a search of five relevant electronic databases: Medline, CINAHL, SocIndex, PsychInfo and ERIC, using relevant search terms (see Table 2).

The search terms were derived from numerous exploratory searches of the literature (as per CRD guidance) [16] and suggestions from experts in this field. We searched for the terms in titles and abstracts.

The search focussed on papers published between January 2005 and July 2015. The start date was chosen due to changes in the importance of primary care in genetic and genomic healthcare at that time, when the emergence of genomics in health shifted the focus of care in genetics from purely specialist services to 
Table 1 Objective and Population, Intervention, Comparison, Outcomes, and Setting (PICOS) [18] elements

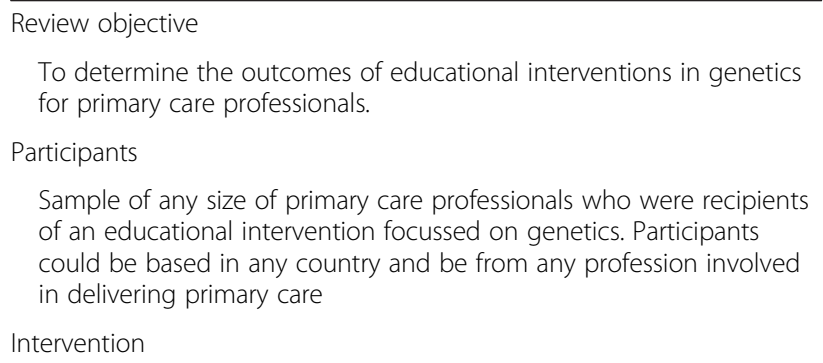

Any educational intervention directed at qualified health professionals in primary care and focussed on genetic healthcare, including but not restricted to online or face to face education lasting one hour or more.

Comparators

None; control group of comparable professionals; control group of comparable practices.

\section{Outcomes}

Any outcomes, including but not restricted to: satisfaction with the educational intervention, changes in knowledge, changes in confidence changes in skills, changes in clinical behaviour, use of acquired genetics competencies, impact on organizational change or impact on patient health.

Study design

Any study design, including RCTs, quasi-experimental studies, cohort studies and qualitative studies.

primary and secondary care. For example, a seminal paper was published in 2003 urging the involvement of a wider health professional community in healthcare using genomics [19], while the same year there was recognition in the UK NHS White Paper [20] that primary care had a role in managing patients with genetic conditions, resulting in subsequent funding of posts for GPs with a special interest in genetics. It was therefore reasonable to expect that papers published in response to these initiatives might appear as early as 2005 . We limited the search to studies that included human participants and were published in English. We also handsearched the reference lists of relevant papers.

Papers were eligible for inclusion if they: i) were reports of primary research using qualitative, quantitative or mixed methods designs, ii) included data on outcomes (i.e. change in knowledge or change in practice) of interventions focussed on genetics education for

Table 2 Search terms

Genet ${ }^{\mathrm{a}}$ OR genom* OR prenatal OR inherited
AND
Primary care OR general pract* OR family pract* OR community pract*
OR midwi*
AND
Educat* OR train* OR teach*

primary care practitioners. Papers were excluded if they: i) focussed on health professionals other than those working in primary care, ii) focussed on patient education, iii) described an intervention but did not report outcomes, iv) reported educational needs without use of an intervention v) provided information on educational interventions but the results for primary care providers could not be separated from results for other professionals. For this purpose, we used the WHO definition of primary care and included practitioners from any healthcare profession who offered ongoing and comprehensive care at the first point of contact, directly accessible to patients [7].

As the purpose of a pilot study [21] is to assess the feasibility and logistics of a further (larger) research study, rather than to test an hypothesis and generate reliable and valid findings, we did not include pilot studies. Papers identified for possible inclusion were assessed by at least two researchers, who independently classified the papers and then discussed any differences of opinion until a consensus was reached [16]. A table of excluded papers and reasons for exclusion is available included as Additional file 1.

The eligible papers were assessed for methodological rigour by two researchers (HS and either DT or MP). Each researcher independently scored the paper using the system described by Kmet et al. [22]; scores were then compared and discussed until a consensus was reached. Kmet et al. [22] provide a checklist of 14 items for a quantitative study and 10 items for qualitative studies. A score of 2 (criterion fully met), 1 (criterion partially met) or 0 (criterion not met) is allocated to each item and the scores are totalled.

\section{Data extraction and synthesis}

Data relating to the methods and main outcomes of each study were extracted and presented in a table. Relevant results or findings from each eligible study were coded and entered into a master table. The results/findings were grouped under themes that were identified inductively (post hoc) (see supplemental material for more detail on the codes and themes). Coding was undertaken by two researchers and reviewed by a third researcher. As the papers were heterogeneous in terms of methods, interventions and outcome measures, neither metaanalysis nor meta-synthesis was possible and we present the findings in a narrative form [16].

Because there were multiple outcomes for numerous studies, we reported every outcome and categorised these according to Kirkpatrick's framework [15] for evaluating educational outcomes. This model can be used to distinguish the impact of education at four levels: valuation (level 1; satisfaction), learning (level 2; knowledge and knowledge retention), behaviour (level 3: applying 
knowledge and consultation skills regarding timely recognition of patients at risk) and effects on patient health and organization (level 4: changes in actual practice performance [i.e. referral] and results). The impact on society, or patient safety in genetic medical care, is part of level 4. The first learning step, according to Moore [23], would be to try and inform primary care health workers and aim for a better understanding of genetics. The first level of Kirkpatrick's framework for evaluating the educational outcome then assesses satisfaction with the genetic modules. The higher the level, the more complex the potential learning outcome of the genetic module and the greater the possibility of having an impact on (genetic) health. We used Moore's model of CPD curriculum design [23], identifying individual learning steps with their educational objectives and used the Kirkpatrick framework as a model to evaluate the genetic modules [15]. These analyses are presented in Table 5 .

\section{Results}

There were twelve papers [24-35] identified for potential detailed review. However, two papers reported the same study [34,35], so eleven papers were reviewed. The characteristics of the eleven individual studies [24-34] are presented in Table 3. The Preferred Reporting Items for Systematic Reviews and Meta-Analyses (PRISMA) flow chart [18] in Fig. 1 shows the selection process and the reasons for exclusion of papers. A list of excluded papers (with reasons for exclusion) is provided in the supplemental material. Regarding quality of the papers reviewed, the consensus quality score totals ranged (as a percentage of the maximum possible score) from 70 to $100 \%$ and as we set the minimum acceptable score at $70 \%$, all eleven papers were deemed eligible for inclusion in the detailed review. We have included the scores and comments in Table 3 to enable judgements on the quality of the evidence to be made.

\section{Overview of the studies}

In the eleven papers included, three studies were undertaken in the United States (US) [27, 31, 33], two in Canada $[25,26]$, three in the United Kingdom (UK) [24, 28, 34], two in the Netherlands $[29,30]$ and one in Australia [32]. The style of delivery and topics covered are reported in Table 4. Six of the interventions were specifically aimed at GPs [26, 27, 29, 30, 33, 34]: the remaining four were aimed more generally at primary care professionals. In all studies, the intervention was assessed by testing changes in knowledge and/or practice. Houwink et al. [29] also tested the practitioner's knowledge, attitudes and skills using a standardised patient. Laberge et al. [31] assessed the impact of their intervention on both clinical practice and genetic teaching of primary care specialists in university settings.
The findings of the synthesis of evidence are presented under five main themes: prior experience, changes in confidence, changes in knowledge, changes in practice, satisfaction and feedback. A detailed table showing categories and themes derived from the paper is available in Additional file 2.

\section{Prior experience}

Authors of only one study reported prior experience that could influence provision of genetic healthcare. Srinivasan et al. [33] found that only 69 (25\%) of the 279 residents training in primary care in their study had experience of genetic conditions amongst family and friends. Of those 69, 35 (12.5\% of total sample) had personal experience of involvement in the care of an affected person and over three quarters had cared for a patient with a genetic condition. While $55 \%$ had ordered a genetic test, none had offered more than a few minutes of counselling to accompany those tests, although it is not stated what proportion of these tests may have been primarily to establish a diagnosis rather than being of a predictive nature. Of 111 GPs attending a workshop on prenatal tests [32], $40 \%$ reported recording the full family history of the patient 'always or often' (p594).

\section{Changes in confidence in offering genetic healthcare}

Practitioner confidence was shown to improve in six of the ten relevant studies, although the methods of assessing confidence differed across the studies. General practitioner confidence measured by Wilson et al. [34] did not significantly alter with respect to taking family history or ability to respond to patient queries about breast cancer risk. Similarly, only $23 \%$ of the 22 practitioners interviewed by Laberge et al. [31] felt more confident in offering genetic healthcare.

However, Bethea et al. [24] reported participants in the intervention practices were more confident than controls (Odds Ratio (OR) 2.50, $p=0.03$ ), especially related to family history collection (OR 2.39, $p=0.02$ ), risk assessment (OR 3.65, $p=0.01$ ) and reassuring those patients whom they assessed as low risk (OR 3.94, $p=$ 0.01). While confidence scores increased across a range of 13 different topics when assessed by Carroll et al. [25], significant differences were found for only six activities or topics: assessing genetic risk $(p=0.033)$, making appropriate referrals $(p=0.033)$, discussing prenatal testing $(p=0.034)$, discussing benefits and limitations of genetic testing $(p=0.033)$, discussing content of a genetic counselling session $(p=0.022)$, and genetics of adult-onset disorders $(p=0.005)$ [25]. Participants in that study also gained confidence in being able to act as a resource for other colleagues with respect to genetics issues. Selfreported confidence in managing prenatal screening issues improved in the study by Metcalfe et al. [32], with $15.9 \%$ 
Table 3 Included studies

Authors, year, Aim

country, funding

source (where

available)

\begin{tabular}{|c|c|c|}
\hline $\begin{array}{l}\text { Bethea et al. } \\
\text { (2008) [24] } \\
\text { United Kingdom. } \\
\text { Funding; UK } \\
\text { Department of } \\
\text { Health and NHS } \\
\text { R\&D. }\end{array}$ & $\begin{array}{l}\text { To determine } \\
\text { the current level } \\
\text { of competence } \\
\text { and confidence } \\
\text { of primary care } \\
\text { professionals in } \\
\text { relation to } \\
\text { management of } \\
\text { familial cancers and } \\
\text { explore how these } \\
\text { were affected by } \\
\text { educational outreach. }\end{array}$ & $\begin{array}{l}\text { Quasi-experimental } \\
\text { design. } \\
\text { Longitudinal } \\
\text { interventional study } \\
\text { using matched groups. } \\
\text { Baseline cross-sectional } \\
\text { survey preceded the } \\
\text { study. } \\
\text { Follow-up data were } \\
\text { collected six months } \\
\text { after the completion } \\
\text { of the intervention. }\end{array}$ \\
\hline
\end{tabular}

GPs and practice
nurses from both
rural and urban areas
of England.
217 practitioners
completed both
pre and post
intervention
surveys: 29 from
intervention group,
188 from non-
intervention group
educational outreach of the intervention.
intervention group.

Participants

\begin{tabular}{|c|c|c|}
\hline $\begin{array}{l}\text { Carroll et al. (2009) } \\
\text { [25] } \\
\text { Canada. } \\
\text { Funding; Ontario } \\
\text { Womens' Health } \\
\text { Council. }\end{array}$ & $\begin{array}{l}\text { 'To increase primary } \\
\text { care providers' } \\
\text { awareness and } \\
\text { knowledge of } \\
\text { genetic issues and } \\
\text { genetic services, as } \\
\text { well as their } \\
\text { confidence in } \\
\text { dealing with genetic } \\
\text { issues and use of }\end{array}$ & $\begin{array}{l}\text { Quasi-experimental } \\
\text { design. Longitudinal } \\
\text { study using a survey } \\
\text { pre-course (T1) and } \\
\text { six months after the } \\
\text { course (T3). Satisfactio } \\
\text { with the programme } \\
\text { was assessed } \\
\text { immediately after the } \\
\text { study day (T2). }\end{array}$ \\
\hline
\end{tabular}

resources.'
Intervention

Analysis
outreach comprising

wo sessions on

familial cancer and one on other genetic onditions (details eported in another paper [36])

Workshop attended professionals but responses to survey from only $21(67 \%$ were family physicians).
One day workshop Descriptive statistics. for primary care professionals.

Educational materials (powerpoint presentations) available after the workshop on the web.
McNemar test and Wilcoxon signed rank test used to assess changes in knowledge and confidence between $\mathrm{T} 1$ and $\mathrm{T} 3$.

Main results

Scores (according

to Kmet et al. [27]

tool) and

comments on

quality issues

$81 \%$

Descriptive statistics

competence. Logistic

regression analysis to

identify differences

and non-intervention

groups.

intervention practices

assessment for breast

cancer (OR 2.50, $p=0.03$

$95 \% \mathrm{Cl} 1.10-5.67)$ and

in knowing family history

to collect (OR 2.39,

$p=0.0295 \% \mathrm{Cl}$

1.14-5.00), make a risk

assessment (OR 3.65,

$p=0.01,95 \% \mathrm{Cl} 1.38-$

9.61)) and reassurance

of low risk patients

(OR 3.94, $p=0.01$

$95 \% \mathrm{Cl} 1.39-11.22)$ in

relation to bowel cancer.

Knowledge was improved

in relation to correct

assignation of breast cancer

in the intervention group

$\left(X^{2}=4.37, d f=1, p=0.04\right)$

Self- assessed confidence

selated to managing Research question adult-onset conditions

increased from pre-course

mean score of 2.3 of a

possible score of 5

Research question and study design

indication of

$(\mathrm{SD}=0.7)$ to post-course

$(\mathrm{SD}=0.9),(p=0.005)$

Self- assessed confidence

in skills related to prenatal

genetics dir

genetics did not

the mean score

pre-course was 3.4

$(\mathrm{SD}=1.1)$ and post score

was $3.6(\mathrm{SD}=1.1)$.

Knowledge increased

regarding hereditary

colorectal cancer: 5/21

attendees answered

correctly pre-course,

compared to $10 / 20$

post course $(p=0.031)$. 
Table 3 Included studies (Continued)

Carroll et al. (2011) [26]

Canada.

Funding: Canadian

Institutes of Health

Research
Evaluation of an

educational

intervention

\section{Randomised controlled}

trial comparing family

practitioners who

received the intervention

with those who did not

Pre-intervention data

collected one month

before intervention and

post-data six month

after intervention.
Family practitioners from a range of practices in Canada: 47 in intervention control group. portfolio of practical tools and knowledge support service covariance used to compare results in the two groups.

\footnotetext{
Clyman et al. (2007) [27]

USA.

Funding: US

Health and

Human Services.
}

To assess the utility of an educational programme in

Quasi-experimental design. Pre and post intervention survey. Knowledge tested immediately after each lecture.
36 GPs who had not $8 \times 60$ min lectures Descriptive had genetic over 2 years and education beyond monthly $45 \mathrm{~min}$ basic medical training. seminars for two years.

paired Stude

t-test.
Those in intervention group scored highly for confidence regarding referral decisions after the intervention. The adjusted mean score of the intervention group was 47.0

(95\% Cl 44.9-49.2) compared with 37.9 (95 \% Cl 35.1-40.7) in the control group. They were more likely to make appropriate referral decisions with an adjusted mean of 7.8 (95\% Cl=7.4-8.2) in the intervention group compared with mean of $6.4(95 \% \mathrm{Cl}=5.8-6.9$ in control group. The intervention group scored more highly on post-intervention knowledge questions, differences in knowledge score ine and intervention groups indicated an odds ratio of 2.56 (95\% Cl 0.90-7.31) for knowledge of the likelihood of a patient having a BRCA mutation, 1.43 (95\% Cl 0.31-6.52) for percentage of women with breast cancer with a BRCA mutation and 1.23 (95\% Cl 0.46-3.28) of number of patients with genetic predisposition to colorectal cancer who will develop the disease.

There was an

improvement in

knowledge after the intervention, with mean pre-intervention score of 61.95 (SD 19.1, $95 \%$ 58.8-65.1), compared with post-intervention
$96 \%$

Sample size small compared to that required to provide $80 \%$ power to detect difference of 0.5 of a SD.
$70 \%$

Sample small and analysis based on score for each participant for each of 8 lectures to higher numbers. 
Table 3 Included studies (Continued)

\begin{tabular}{|c|c|c|c|c|}
\hline $\begin{array}{l}\text { Emery et al. } \\
\text { (2007) [28] } \\
\text { United Kingdom. } \\
\text { Funding: Cancer } \\
\text { Research UK and } \\
\text { NHS R\&D Support } \\
\text { for Science. }\end{array}$ & $\begin{array}{l}\text { Assessment of use of } \\
\text { risk assessment } \\
\text { software in } \\
\text { conjunction with } \\
\text { education. }\end{array}$ & $\begin{array}{l}\text { Randomised } \\
\text { controlled trial. } \\
\text { Follow-up } 12 \text { months } \\
\text { after intervention } \\
\text { introduced. }\end{array}$ & $\begin{array}{l}45 \text { practice teams - } \\
23 \text { in intervention } \\
\text { group and } 22 \text { in } \\
\text { control group. }\end{array}$ & $\begin{array}{l}45 \text { min training } \\
\text { session on cancer } \\
\text { genetics. Lead } \\
\text { clinicians for the } \\
\text { research in each } \\
\text { practice attended } \\
\text { an additional } 90 \\
\text { min session on } \\
\text { using the software }\end{array}$ \\
\hline
\end{tabular}

Houwink et al. (2014) To determine

A blinded, randomized [30] Netherlands.

Funding: Netherlands whether primary care controlled trial (RCT)

Genomics Initiative.

practitioners' genetic

knowledge improved intervention group

longer term through (received education)

an oncogenetic

training programme and control group.

months after training.
80 Dutch GPs working $2 \mathrm{~h}$ online genetics in family practice: 40 education course.

in intervention group

and 40 in contro

group. 24 from

intervention group

and 20 from control

group completed the

study scores of $76.1 \%$ (SD 16.8,

$95 \% \mathrm{Cl} 73.3-78.9,9)$

$\left(p<1 \times 10^{-10}\right)$.

Use of software thes

models used to

analyse referral

appropriateness.

was 62 (S

was 6.2 (SD 3.1) per

per year, compared to a

mean of 3.2 (SD 2.8) in

control practices. The

odds ratio of intervention

vs control practices in

referring patients in

accordance with referra

guidelines was 5.2

(95 \% Cl 1.7-15.8)

and referred patients

were more likely to have

an increased risk of cance

when assessed by the

genetic service (OR 0.7,

$$
95 \% \text { Cl 0.3-1.5 }
$$

Mean (test scores)

and regression

analysis.

More precise estimations

of knowledge gained

were obtained by the

regression analysis. The

effect of the intervention

was found to be

statistically significant,

amounting to 0.055 on

the proportion correct

scale; the corresponding

value for the standardized

regression coefficient was 27. indicating an almost 27, indicating an almost moderate effect size at T1.
This value further increased 6 months after the

intervention (.34, moderate effect size).

Global score for satisfaction was 7.9/10 (SD 1.3, $95 \%$ Cl 7.5-8.3) while applicability scores were more diverse neutral scores for

recognition of disease,

referral to a specialist and knowledge of possibilities/ limitations of genetic testing (2.7-2.9). The scores
$96 \%$

Incomplete contro of confounding variables.

$84 \%$

Small sample size

ue to large attrition rate. 
Table 3 Included studies (Continued)

$\begin{array}{lll}\text { Houwink et al. (2014) } & \text { To determine } & \text { A blinded, randomized } \\ \text { [29] Netherlands. } & \text { whether primary care } & \text { controlled trial (RCT) } \\ \text { Funding: Netherlands } & \text { practitioners' genetic } & \text { comparing an } \\ \text { Genomics Initiative. } & \text { skills improved } & \text { intervention group } \\ & \text { through an } & \text { (received education) } \\ & \text { oncogenetics } & \text { and control group. } \\ & \text { training programme. } & \text { Follow-up occurred } \\ & & \text { three months after } \\ & \text { training. }\end{array}$

Laberge et al. (2009)

[31] US.

Funding:

Maternal and Child

Health Bureau of

the Health resources

and Services

Administration.

Metcalfe et al.

(2005) [32]

Australia.

Funding: no stated

funding source.
To evaluate the long term impact of the Genetics in Primary Care Project, a genetics educational programme to prepare primary care physicians for

$\begin{array}{ll}\text { physicians for } & \text { exacty specified, but } \\ \text { practice. } & 3-4 \text { years after }\end{array}$

Qualitative descriptive study based on

content analysis. Data collected during site visits or telephone to interview teachers. $3-4$ years after
completion of the

programme.

To determine the Quasi-experimental effects of an design

educational

Single group pre-test

intervention on

GP knowledge of prenatal tests. design

Questionnair
56 (38 in intervention $4 \mathrm{~h}$ face to face group, 18 in control training in

group) GPs from two oncogenetics. Dutch provinces.
Teams from 20 institutions.

111 GPs who attended one of

three workshops on three workshops on provided prenatal testing. All

for increased knowledge

about genetic diseases and

basic genetic concepts

were 3.3-3.8.

Descriptive statistics and regression analysis. favor of the intervention immediate effect at $\mathrm{T} 1$.

Genetics in Primary Care Content analysis. Project programme included: 1) "train

the trainer" workshops

and (2) informal teaching

in the medical school/

residency curricula. administered
One face to face educational

workshop based on two prenatal cases.
Frequencies and to compare differences in means. Independent samples $t$-tests for comparisons between groups. ween group differences were found to be nonsignificant for the pretest (T) and retention (T2) test, but the posttest (T1) difference of 0.19 in group was found to be significant ( $t$-test; $p<0.0005)$. Standardised regression coefficient for the effect of the training on skills was 34 at $\mathrm{T} 1(95 \% \mathrm{Cl}$ .05-.23) one month after the training and .28 at T2 (95\% Cl .03-.20) two months later, both indicating moderate effect size. Performance improvement in the intervention group at $\mathrm{T} 2$ was $80 \%$ of the Mean satisfaction and self-reported applicability scores were combined

7.7/10, SD 1.9, 95 \% Cl

6.7-8.6).

$77 \%$ High number of non-

responders, high attrition rate, especially in control group. .

Little background connecting to theoretical framework or body of knowledge. Interviews described but content of site visits not clear.

$95 \%$

Number of GPS feeling quite or very confident about

Confidence was

self-reported prenatal screening

measure. 
Table 3 Included studies (Continued)

\begin{tabular}{|c|c|c|c|c|c|c|c|}
\hline & & $\begin{array}{l}\text { pre-workshop, } \\
\text { post-workshop } \\
\text { and 6-8 months } \\
\text { later. }\end{array}$ & & & $\begin{array}{l}\text { ANOVA to identify } \\
\text { factors influencing } \\
\text { scores. }\end{array}$ & $\begin{array}{l}\text { post workshop and } \\
45.1 \% \text { 6-8 months later. } \\
\text { Knowledge of prenatal } \\
\text { screening and testing } \\
\text { was significantly improved } \\
\text { from a mean of } 51.2 \% \\
\text { (SD } 1.59,95 \% \mathrm{Cl} \\
48.02-54.39) \text { pre } \\
\text { intervention to } 62.88 \% \\
\text { (SD 1.51, } 95 \% \mathrm{Cl} \\
59.86-65.89 \text { ) post } \\
\text { workshop and } 58.92 \% \\
\text { (SD 1.6, } 95 \% \mathrm{Cl} \\
55.71-62.12 \text { ) at follow up. }\end{array}$ & \\
\hline $\begin{array}{l}\text { Srinivasan et al. } \\
\text { (2011) [33] } \\
\text { US. } \\
\text { Funding: National } \\
\text { Human Genome } \\
\text { Research Institute. }\end{array}$ & $\begin{array}{l}\text { To evaluate a web- } \\
\text { based progamme } \\
\text { on ELSI issues in } \\
\text { genetics for primary } \\
\text { care residents }\end{array}$ & $\begin{array}{l}\text { Quasi-experimental } \\
\text { design. Longitudinal } \\
\text { study, using pre and } \\
\text { post course surveys } \\
\text { that covered prior } \\
\text { experience, self-efficacy } \\
\text { and knowledge of } \\
\text { genetics. } \\
\text { Follow-up data collected } \\
\text { after completion of the } \\
\text { curriculum (exact period } \\
\text { of time not given). }\end{array}$ & $\begin{array}{l}210 \text { primary care } \\
\text { residents in } \\
\text { paediatrics, internal } \\
\text { medicine or family } \\
\text { medicine, all were } \\
\text { enrolled at one of } \\
\text { three institutions. }\end{array}$ & $\begin{array}{l}\text { Web-based } \\
\text { educational } \\
\text { programme based } \\
\text { on ten cases and } \\
\text { five tutorials. Each } \\
\text { participant studied } \\
\text { five cases and } \\
\text { two tutorials. }\end{array}$ & $\begin{array}{l}\text { Changes in self-efficacy } \\
\text { and knowledge were } \\
\text { analysed using the } t \text {-test. } \\
\text { Anova was used to } \\
\text { compare levels of } \\
\text { experience in genetics } \\
\text { between specialties. } \\
\text { Descriptive statistics for } \\
\text { non-parametric values. }\end{array}$ & $\begin{array}{l}\text { Mean pre-test knowledge } \\
\text { scores were } 9.6 / 14 \text {, } \\
\text { compared with post } \\
\text { scores of } 10 / 14 \text {. } \\
\text { Overall self-efficacy } \\
\text { increased from pre-course } \\
\text { mean of } 71.2 \\
\text { to post-course mean } \\
\text { of } 83.4 \text {. }\end{array}$ & $\begin{array}{l}73 \% \\
\text { Little description } \\
\text { of sample } \\
\text { demographics. } \\
\text { In two centres, } \\
\text { the course was } \\
\text { mandatory, which } \\
\text { will have } \\
\text { influenced uptake. }\end{array}$ \\
\hline $\begin{array}{l}\text { Wilson et al. } \\
\text { (2006) [34] } \\
\text { UK. } \\
\text { Funding: NHS } \\
\text { R7D Health } \\
\text { Technology } \\
\text { Assessment } \\
\text { Programme. }\end{array}$ & $\begin{array}{l}\text { To determine if } \\
\text { GP confidence in } \\
\text { managing patients } \\
\text { with a family history } \\
\text { of breast cancer was } \\
\text { altered by use of } \\
\text { educational session } \\
\text { and a condition- } \\
\text { specific software } \\
\text { tool. }\end{array}$ & $\begin{array}{l}\text { Pragmatic cluster } \\
\text { randomised controlled } \\
\text { trial. } \\
\text { Intervention arm received } \\
\text { software and training. } \\
\text { Follow-up data were } \\
\text { collected at the end } \\
\text { of the one year } \\
\text { intervention period. }\end{array}$ & $\begin{array}{l}\text { GPs working in } \\
\text { specific practices in a } \\
\text { region in Scotland. } \\
\text { Practices were } \\
\text { assigned to either } \\
\text { the control or } \\
\text { intervention groups. }\end{array}$ & $\begin{array}{l}\text { Software on CD- } \\
\text { ROM was sent to } \\
\text { each practice in } \\
\text { intervention } \\
\text { group. GPs in } \\
\text { those groups } \\
\text { were sent an } \\
\text { individual letter } \\
\text { about the study } \\
\text { and invited to one } \\
\text { educational } \\
\text { session on use of } \\
\text { software. Only } \\
11.9 \% \text { of GPs in } \\
\text { intervention group } \\
\text { attended an } \\
\text { educational session. }\end{array}$ & $\begin{array}{l}\text { Chi-square tests, } \\
\text { intracluster relation } \\
\text { coefficient. }\end{array}$ & $\begin{array}{l}\text { No significant differences } \\
\text { reported between } \\
\text { intervention and control } \\
\text { groups in changes in GP } \\
\text { confidence in managing } \\
\text { patients, referral patterns, } \\
\text { or initial patient risk } \\
\text { assessment. }\end{array}$ & $\begin{array}{l}96 \% \\
\text { Confidence in } \\
\text { managing patients } \\
\text { was self-reported } \\
\text { measure. }\end{array}$ \\
\hline
\end{tabular}




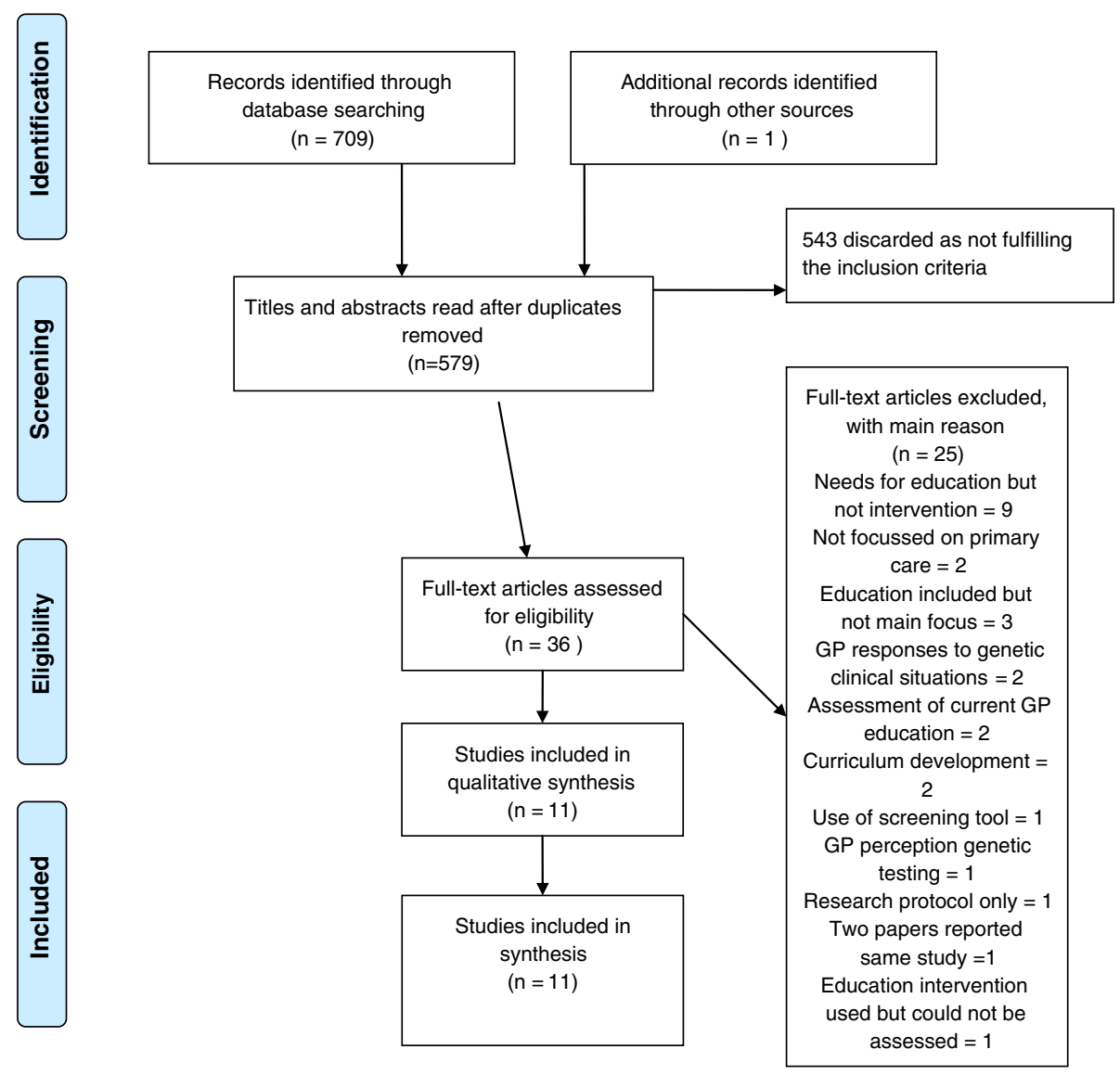

Fig. 1 PRISMA 2009 flow diagram

of GPs feeling quite or very confident pre-workshop, compared with $81.9 \%$ post-workshop and $45.1 \%$ six to eight months later.

Those in the intervention group studied later by Carroll et al. [26] reported more confidence across a range of competencies (adjusted mean score of 37.9/55 in control group compared to 47.0/55 in intervention group) and scored higher than the control group on the topic of making referral decisions (7.8/10 compared with 6.4/10). Confidence was assessed in only the lead clinicians in Emery et al.'s study [28]: their self-reported confidence in managing patients with a family history of cancer improved after training $(p<0.001)$ and remained higher than baseline levels for the following twelve months.

Self-efficacy was measured in the study of medical residents by Srinivasan et al. [33], who reported that confidence in genetic skills increased from a mean of 71 (possible range 23-115) to a mean of 83.4. Specifically, mean scores for confidence in their own genetics knowledge was 11.7 pre-course (possible range of 4-20), rising to 14.1 post course, a significant difference $(p<0.01)$. However, as can be seen in the section below, this was not always matched by actual changes in knowledge as assessed by the researchers.

\section{Changes in knowledge}

Authors of five studies reported improvements in knowledge of attendees. Carroll et al. [25] tested a small sample of 21 participants' awareness of genetic services pre and post course and found no significant differences. Knowledge of breast and ovarian cancer was not shown to increase in participants, however a question on colorectal cancer was answered correctly by significantly more primary care providers $(24 \%$ pre-course increasing to $50 \%$ post-course, $p=0.031)$. Although intervention participants had higher knowledge scores than controls in another study led by Carroll [26] (adjusted mean score of 47.0/55 in the intervention group compared to $37.9 / 55$ in control group), the difference was not significant, nor was overall knowledge of genetics significantly changed in the study by Srinivasan et al. [33].

However, Houwink et al. [30] measured genetics knowledge using a test comprising 20 multiple choice items at three time points and found that knowledge had improved in the intervention group post-course and 
Table 4 Details of educational interventions by study

\begin{tabular}{|c|c|c|c|c|c|}
\hline Study & Educational theory & Type of delivery & Focus & Content & Cases \\
\hline $\begin{array}{l}\text { Bethea et al. } \\
\text { (2008) [24] }\end{array}$ & $\begin{array}{l}\text { Educational outreach } \\
\text { (Thomson et al. } 2001 \text { [36]) }\end{array}$ & $\begin{array}{l}\text { 1. Tailored input into primary care } \\
\text { practices by a genetic counsellor. } \\
\text { 2. Face to face update sessions on } \\
\text { relevant topics ( } 3 \text { sessions offered) } \\
\text { 3. Practical tools such as referral } \\
\text { guidelines and family history forms. } \\
\text { 4. Opportunity for genetic counsellor } \\
\text { to deal with patient queries. }\end{array}$ & $\begin{array}{l}\text { To facilitate use of familial cancer guidelines } \\
\text { and provide support to primary care on } \\
\text { genetics issues. }\end{array}$ & $\begin{array}{l}\text { Update sessions on: } \\
\text { - Familial cancer referral guidelines } \\
\text { - Risk assessment } \\
\text { - Support and management of } \\
\text { patients. }\end{array}$ & $\begin{array}{l}\text { - Hereditary breast and } \\
\text { ovarian cancer } \\
\text { - hereditary bowel cancer } \\
\text { cancer } \\
\text { - haemochromatosis, cystic } \\
\text { fibrosis, Marfan syndrome, } \\
\text { fragile X and } \\
\text { hypercholestrolaemia. }\end{array}$ \\
\hline $\begin{array}{l}\text { Carroll et al. } \\
\text { (2009) [25] }\end{array}$ & Not stated & $\begin{array}{l}\text { One-day face to face interactive } \\
\text { workshop. Powerpoint files available } \\
\text { online later. }\end{array}$ & $\begin{array}{l}\text { To increase confidence of professional to } \\
\text { become a resource on genetic health for } \\
\text { other professionals in their communities }\end{array}$ & $\begin{array}{l}\text { - Family history taking } \\
\text { - Risk assessment } \\
\text { - Referral to genetic services } \\
\text { - Advantages and disadvantages of } \\
\text { genetic testing } \\
\text { - Obtaining resources } \\
\text { - Ethical issues }\end{array}$ & $\begin{array}{l}\text { - Alzheimer disease } \\
\text { - hereditary breast cancer } \\
\text { - hereditary colon cancer } \\
\text { - cystic fibrosis } \\
\text { - haemochromatosis } \\
\text { - prenatal genetic screening. }\end{array}$ \\
\hline $\begin{array}{l}\text { Carroll et al. } \\
\text { (2011) [26] }\end{array}$ & Not stated & $\begin{array}{l}\text { One face to face interactive workshop } \\
\text { session of } 60 \text { min. } \\
\text { Portfolio of tools that could be used } \\
\text { in primary care practice. } \\
\text { Information sheet on current topics } \\
\text { sent to participants every two weeks } \\
\text { during the trial. }\end{array}$ & $\begin{array}{l}\text { To improve referral decisions, confidence and } \\
\text { knowledge relevant to primary care genetics. }\end{array}$ & $\begin{array}{l}\text { - Practical medical genetics } \\
\text { information } \\
\text { - Risks, benefits and limitations of } \\
\text { genetic testing including } \\
\text { psychosocial risks, confidentiality } \\
\text { and insurance issues. }\end{array}$ & $\begin{array}{l}\text { - Hereditary breast and } \\
\text { ovarian cancer } \\
\text { - Hereditary colorectal } \\
\text { cancer. }\end{array}$ \\
\hline $\begin{array}{l}\text { Clyman et al. } \\
\text { (2007) [27] }\end{array}$ & $\begin{array}{l}\text { Evidence based } \\
\text { approach (Davis } \\
\text { et al. } 1995 \text { [37]) }\end{array}$ & $\begin{array}{l}\text { Over two years, a } 60 \text { min face to face } \\
\text { lecture each quarter ( } 8 \text { lectures in } \\
\text { total) and a monthly } 45 \text { min didactic } \\
\text { seminar. }\end{array}$ & $\begin{array}{l}\text { To enable family physicians to provide } \\
\text { appropriate services to patients with family } \\
\text { or personal history of birth defects or mental } \\
\text { retardation. }\end{array}$ & $\begin{array}{l}\text { - Prenatal genetics } \\
\text { - Maternal serum screening } \\
\text { - Principles of medical genetics } \\
\text { - Cytogenetics } \\
\text { - Pedigree clinic } \\
\text { - Dysmorphology in primary care } \\
\text { - Genetics of common inherited } \\
\text { disorders } \\
\text { - Inherited cancer syndromes in } \\
\text { primary care } \\
\text { - Biochemical genetics } \\
\text { - Genetic testing } \\
\text { - Prenatal ultrasound anomalies }\end{array}$ & $\begin{array}{l}\text { - States case-based approach } \\
\text { but no examples given. }\end{array}$ \\
\hline $\begin{array}{l}\text { Emery et al. } \\
\text { (2007) [28] }\end{array}$ & Not stated. & $\begin{array}{l}\text { Computer decision support tool for } \\
\text { familial cancer. } \\
\text { One } 45 \text { min face to face educational } \\
\text { session on familial cancer for medical } \\
\text { and nursing staff in participating } \\
\text { practices. } \\
\text { One } 90 \text { min training session for lead } \\
\text { clinician on use of the software. }\end{array}$ & Familial cancer risk assessment. & $\begin{array}{l}\text { - Risk assessment for familial cancer } \\
\text { - Referral guidelines for familial } \\
\text { cancer. }\end{array}$ & None stated. \\
\hline $\begin{array}{l}\text { Houwink et al. } \\
\text { (2014) [29] }\end{array}$ & $\begin{array}{l}\text { Kirkpatrick (1967) [15] } \\
\text { framework }\end{array}$ & $\begin{array}{l}4 \mathrm{~h} \text { face to face training programme, } \\
\text { including role play. }\end{array}$ & Oncogenetic consultation skills & $\begin{array}{l}\text { - Family history taking } \\
\text { - Genetic risk assessment } \\
\text { - Referral } \\
\text { - Ethical issues }\end{array}$ & $\begin{array}{l}\text { Hereditary cancers: } \\
\text { - Breast and ovarian cancer } \\
\text { - Colorectal cancer } \\
\text { - Skin cancer. }\end{array}$ \\
\hline
\end{tabular}


Table 4 Details of educational interventions by study (Continued)

\begin{tabular}{|c|c|c|c|c|c|}
\hline $\begin{array}{l}\text { Laberge et al. } \\
\text { (2009) [31] }\end{array}$ & Not stated & $\begin{array}{l}\text { Eight case-based modules delivered } \\
\text { to trainers in a national workshop } \\
\text { over a period of six months }\end{array}$ & $\begin{array}{l}\text { Enhance faculty ability to teach genetics to } \\
\text { primary care trainees. }\end{array}$ & Not supplied & $\begin{array}{l}\text { Not supplied in the paper. } \\
\text { Retrieved from Burke et al. } \\
(2002)[38,42] \text {. }\end{array}$ \\
\hline $\begin{array}{l}\text { Metcalfe et al. } \\
\text { (2005) [32] }\end{array}$ & Not stated & $\begin{array}{l}\text { One case-based workshop (duration } \\
\text { not stated). } \\
\text { Participants also given an information } \\
\text { pack including materials about the } \\
\text { genetic service. }\end{array}$ & $\begin{array}{l}\text { Enhance GP knowledge of prenatal tests in } \\
\text { practice }\end{array}$ & $\begin{array}{l}\text { - Prenatal counseling } \\
\text { - Prevalence of birth defects } \\
\text { - Counseling and informed choice } \\
\text { - Screening for thalassaemia } \\
\text { - Screening versus diagnostic testing } \\
\text { - Pre-implantation genetic diagnosis }\end{array}$ & $\begin{array}{l}\text { Two cases. Content not } \\
\text { stated. }\end{array}$ \\
\hline $\begin{array}{l}\text { Srinivasan et al. } \\
\text { (2014) [33] }\end{array}$ & $\begin{array}{l}\text { Kern (1998) [38] - } \\
\text { curricular development } \\
\text { model }\end{array}$ & Interactive web-based programme. & ELSI genetics & $\begin{array}{l}\text { - Core concepts in genetics } \\
\text { - ELSI cultural issues } \\
\text { - Medical ethics and law } \\
\text { - Risk metrics/disease screening } \\
\text { - Maternal fetal medicine. }\end{array}$ & $\begin{array}{l}\text { - Alzheimer disease } \\
\text { - androgen insensitivity } \\
\text { - breast cancer } \\
\text { - colon cancer } \\
\text { - cystic fibrosis } \\
\text { - Down syndrome } \\
\text { - haemochromatosis } \\
\text { - Huntington disease } \\
\text { - Klinefelter syndrome } \\
\text { - thrombophilia. }\end{array}$ \\
\hline $\begin{array}{l}\text { Wilson et al. } \\
\text { (2005) [34] }\end{array}$ & Not stated & $\begin{array}{l}\text { Educational session on cancer } \\
\text { genetics and use of relevant clinical } \\
\text { software. }\end{array}$ & Cancer genetics & $\begin{array}{l}\text { - Referral guide } \\
\text { - Genetic basis of cancers } \\
\text { - Patient information } \\
\text { - Contact information for local } \\
\text { specialists. }\end{array}$ & $\begin{array}{l}\text { - Breast and ovarian cancer } \\
\text { - colorectal cancer. }\end{array}$ \\
\hline
\end{tabular}

- Clinical knowledge required for

cancer genetics.

- Family history taking

- Genetic risk assessment

Hereditary cancers:

- Common types of hereditary

cancer

- Referral guidelines

- Possibilities and limitations of

genetic testing

- Clinical surveillance options

Eight case-based modules delivered

One case-based workshop (duration Participants also given an information pack including materials about the 
six months post-course. Professionals in participating practices correctly assigned risk in relation to familial breast cancer more frequently than those from nonparticipating practices $(p=0.04)$ in the study by Bethea et al. [24], while Clyman et al. [27] showed significant improvement in knowledge of family physicians postcourse $\left(p<1 \times 10^{-10)}\right.$ and that they were less likely to over-refer or under-refer in the context of a hypothetical scenario. Metcalfe et al. [32] tested knowledge of prenatal screening, appropriate prenatal tests and risks of recessive inheritance and Down syndrome and the scores improved significantly from a mean of 51.2 preworkshop to 62.88 post-workshop $(p<0.001)$ and 58.92 at follow up $(p<0.001)$.

\section{Changes in practice}

Successful educational outcomes are those that lead to applications in practice. Such outcomes are difficult to assess when methods for reporting vary, and behaviour changes as a result of applying new knowledge may not reflect improvements in practice.

Houwink et al. [29] used standardised patient consultations (using trained actors) in a randomised controlled trial (RCT) to measure improvement in GP responses to familial cancer situations in practice pre-course, one month post-course and three months after oncogenetics training for GPs. Regression analyses revealed a moderate effect size for changes in performance in the intervention group between pre-test and post test score (standardised regression co-efficient $=0.34$ ) and between one month post-test and three months post-test (standardised regression co-efficient $=0.28$ ). Similarly, GPs who did a prenatal workshop were more likely to report discussing testing with all their pregnant patients $(69.4 \%$ pre workshop compared with $95.2 \%$ post workshop and $85.7 \%$ at follow up) [32].

Clyman et al. [27] showed no changes in referral pattern of course attendees. Wilson et al. [34] reported that patient referrals to genetic services did not significantly alter $(p=0.56)$ in the intervention group after the course and software package had been offered. However, those who had undergone the intervention were more likely to refer patients who were eventually assessed as having a high or moderate risk of inherited breast cancer, indicating a change in appropriateness of referrals. Referrals to cancer genetic services increased from those in the GRAIDS trial intervention practices [28], however when risk assessments of referred patients were made by specialist genetic staff, there were no differences found between risks to those referred by intervention practices and those referred by comparison practices.

When asked about whether they used the content of the programme in their practice following the course, $13 \%$ of residents surveyed by Srinivasan et al. [33] replied that they used it often, $57 \%$ occasionally and $29 \%$ never. Houwink et al. [30] reported that $90 \%$ of practitioners applied the knowledge at least once a month after the online course, $5 \%$ indicated a frequency of use of at least once a week, while no participant reported daily application and another $5 \%$ reported not encountering genetic issues in their practice. However, the authors did not assess the use of genetic knowledge prior to the course, so it is difficult to be certain how much difference the course actually made. In addition, while participants reported changes in knowledge, they did not report improvements in clinical skills. The primary care practitioners interviewed by Laberge et al. [31] were clinicians who were also involved in providing medical education. During telephone interviews with 22 respondents, $28 \%$ reported changes in referral patterns for genetic healthcare, $23 \%$ gave more consideration to genetics in the differential diagnosis, and $23 \%$ said they put more emphasis on family history. Overall, $82 \%$ indicated that the course had changed their clinical practice in some way, however this was not explored further. In another study ${ }^{17}$, $76 \%(n=32)$ attendees said their practice had changed a little, $21 \%(n=9)$ believed it had changed a lot. Where changes occurred, the nature of the change was unclear.

Primary care providers attending the course offered by Carroll et al. [25] were asked if their practice would change: 15 (86 \%) intended to improve their family history taking and $10(48 \%)$ intended to increase their teaching activity in genetics.

\section{Satisfaction and feedback}

Overall, participants reported satisfaction with the educational programmes studied. The residents in the study by Srinivasan et al. [33] reported that the programme delivered via the web offered more flexibility, but less contact with teaching staff than their usual programme. They did indicate that the web-based course was effective in teaching communication strategies, medical management and ethical, legal and social (ELSI) issues. The mean rating for satisfaction by GPs who took the course provided by Houwink et al. [29] was 7.7 of a possible 10, based on two Likert scales. In the other study by those authors [30], the mean satisfaction score was 7.9/10 (Standard deviation $(\mathrm{SD})=1.3$ ). While participation in the genetics in primary care educational project [31] was seen as worthwhile by all participants, the additional workload and time required to participate were seen as reasons to advise colleagues to consider carefully before committing to it. The majority of those who evaluated the course offered by Carroll et al. [25] believed the course was relevant to them $(24 / 28,86 \%)$ and that learning genetics with other primary care professionals was helpful (26/28, $96 \%)$, while the Genetikit [26] course and materials were rated as either useful or very 
useful by over three-quarters of attendees. Eight lectures offered by Clyman et al. [27] were regarded as of good quality by $96 \%$ of attendees and $81 \%$ believed the course would be useful in practice and $97.1 \%$ GPs attending the prenatal screening workshop provided by Metcalfe et al. [32] believed it would be useful for practice.

Finally, we present in Table 5 the findings of each paper aligned to the educational models of Kirkpatrick [15] and Moore [23], showing that authors of only four studies addressed Level IV, assessing organisational and healthcare impact.

\section{Discussion}

The aim of this review was to ascertain the effectiveness of educational interventions on genetics for primary care. Practitioner confidence was positively affected in six of the eight studies where that factor was investigated, however even in those studies confidence was generally not enhanced across the entire range of possible topics. The interventions were therefore limited in increasing confidence. Knowledge of genetics topics improved in five studies, but again this tended to be subject specific and long term follow up indicated that the level of knowledge gain was not sustained. In only one of three RCTs where knowledge was tested were the changes significant. Overall, significant changes in practice were not demonstrated, with several studies showing no change and one RCT showing only a moderate effect size. While authors of some studies reported changes in practice, these were quasi-experimental or qualitative studies where the evidence was based on self-reports. While learners appeared satisfied with the programmes offered, the range of different questions posed by authors with respect to satisfaction makes the results difficult to interpret.

There are limitations to this study. Although the authors of the review followed a rigorous process to retrieve, select and analyse the available studies, the smallness of the samples and diversity of the studies made it difficult to draw coherent and robust conclusions from the evidence. In particular, we were unable to conduct a mathematical synthesis of the results. It should also be borne in mind that the search was restricted to papers published in English, so there may be evidence published in other languages that has not been included. We searched for peer-reviewed publications, so there may also be some bias due to the omission of unpublished data or results that were only available through the grey literature. However, the rigour of the study was enhanced by the use of more than one researcher to select, appraise and analyse the included papers and the search strategy was constructed based upon numerous trial database and hand searches, so we are reasonably confident that the relevant papers were retrieved.

Previous studies have cited that lack of knowledge about genetics issues, such as genetic tests, acted as a barrier to physician use [25]. In some studies included in this review, knowledge was not significantly altered: where changes occurred these tended to be as a result of prolonged exposure to genetics information, rather than

Table 5 Analysis of papers using Kirkpatrick model

\begin{tabular}{|c|c|c|c|c|c|}
\hline $\begin{array}{l}\text { Kirkpatrick/Moore levels } \\
\text { of education and evaluation }\end{array}$ & Kirkpatrick definition & $\begin{array}{l}\text { Genetics module } \\
\text { format }\end{array}$ & Assessment & Educational objective & Studies \\
\hline | & Satisfaction & $\begin{array}{l}\text { G-CPD or G-eCPD, live } \\
\text { module, supportive } \\
\text { website }\end{array}$ & $\begin{array}{l}\text { Satisfaction, } \\
\text { questionnaire }\end{array}$ & $\begin{array}{l}\text { Information, } \\
\text { understanding }\end{array}$ & $\begin{array}{l}\text { Houwink et al. [29] } \\
\text { Houwink et al [30] }\end{array}$ \\
\hline$\|$ & $\begin{array}{l}\text { Knowledge, self-reported } \\
\text { competences of newly } \\
\text { learned consultation skills }\end{array}$ & $\begin{array}{l}\text { G-eCPD, G-CPD, live } \\
\text { module }\end{array}$ & $\begin{array}{l}\text { Multiple-choice } \\
\text { questions, open } \\
\text { ended questions, } \\
\text { vignettes: pre/post } \\
\text { and retention test }\end{array}$ & $\begin{array}{l}\text { Information, } \\
\text { understanding }\end{array}$ & $\begin{array}{l}\text { Bethea et al. [24] } \\
\text { Carroll et al. [25] } \\
\text { Carroll et al. [26] } \\
\text { Clyman et al. [27] } \\
\text { Emery et al. [28] } \\
\text { Houwink et al. [29] } \\
\text { Houwink et al. [30], } \\
\text { Laberge et al. [31] } \\
\text { Metcalfe et al. [32] } \\
\text { Srinivasan et al. [33] } \\
\text { Wilson et al. [34] }\end{array}$ \\
\hline$\|$ & Behavioural change & Live module & $\begin{array}{l}\text { Responses to SP } \\
\text { encounters in } \\
\text { actual practice: } \\
\text { pre/post and } \\
\text { retention test }\end{array}$ & $\begin{array}{l}\text { Synthesis, application, } \\
\text { performance, attitude }\end{array}$ & $\begin{array}{l}\text { Carroll et al. [26] } \\
\text { Clyman et al. [27] } \\
\text { Emery et al. [28] } \\
\text { Houwink et al. [29] } \\
\text { Laberge et al. [31] } \\
\text { Srinivasan et a.l [33] } \\
\text { Wilson et al. [34] }\end{array}$ \\
\hline IV & $\begin{array}{l}\text { Impact on organizational } \\
\text { change and health gain, } \\
\text { sustained change in practice } \\
\text { behaviour and use of acquired } \\
\text { genetics competencies }\end{array}$ & $\begin{array}{l}\text { G-eCPD, live module, } \\
\text { supportive website } \\
\text { or other practical } \\
\text { clinical genetic tool } \\
\text { such as GenetiKit }\end{array}$ & $\begin{array}{l}\text { GP referral data to } \\
\text { genetics services }\end{array}$ & $\begin{array}{l}\text { Analysis, synthesis, } \\
\text { evaluation: health } \\
\text { gain through timely } \\
\text { (increased) referral to } \\
\text { clinical genetics centers }\end{array}$ & $\begin{array}{l}\text { Carroll et al. [26] } \\
\text { Emery et al. [28] } \\
\text { Laberge et al. [31] } \\
\text { Wilson et al. [34] }\end{array}$ \\
\hline
\end{tabular}


short or one-off courses, but longer courses may be difficult for practitioners to access in terms of availability and time constraints. Some medical educators $[39,40]$ have suggested that 'just in time' information is required to ensure that practitioners can readily access information when their motivation is strongest, i.e. at the point of patient care. Patient queries appear to be related mainly to familial cancers, prenatal and reproductive questions and, less frequently, specific single gene disorders [25].

Raising primary care providers' confidence through better organizational help and education would potentially enable them to apply genetics in practice, implement personalized genetic risk assessment for patients and potentially increase receptiveness to additional genetics education and training. However the self-confidence of primary care physicians in their ability to provide genetic healthcare is known to be generally low, for example Rinke et al. [41] found that although primary care paediatricians in the US reported that they frequently managed children with genetic conditions, they felt they lacked competence to deal with genetic issues. Many had however ordered genetic tests (although the authors did not distinguish between predictive and diagnostic tests) and referred patients to a genetic specialist: major reasons for referral were to obtain information about management and because of parental queries that they presumably felt they could not answer adequately. However, in this review we found that confidence of practitioners did generally improve following the educational programmes, in particular regarding genetic risk assessment. Improved confidence may well result in more appropriate referrals, rather than an increase in referrals, as practitioners become more certain of their ability to reassure patients at low risk. While many of the researchers in our review measured changes in referral numbers, further studies are needed to explore this in detail.

In the study by Burke et al. [11], risk assessment was seen by practitioners who were not genetic specialists as an important educational topic for them. Student motivation to learn is key to successful educational initiatives, and these results may indicate that primary care providers recognise risk assessment as a skill that is required to respond effectively to patients, and are therefore more willing to integrate the information on this topic into their practice. The fact that participants in one study [34] referred patients in the high risk group more appropriately for further genetic healthcare would seem to support this idea. Relevant to this point, Grol and Grimshaw [13] conclude that as well as educational opportunities, other strategies are also needed to support practical change, such as use of support at a policy level and provision of clinical decision aids. They also cite better reimbursement for genetics-related activities as an incentive, which concurs with the findings of Rinke et al. [41].
Three strong methodological issues emerge from this review. One is the difficulty in measuring the effectiveness of the learning activity. Some authors have measured changes in referral rate to genetic services, but in fact an increase in inappropriate referrals may indicate poor learning. Another strategy has been the observation of the proportion of trainees applying the learned knowledge [30], although, again, it is not necessarily a measure of the quality of their clinical application. A more nuanced approach than simply counting referrals is required. Wilson et al. [34], for example, investigated physician referrals based on how they classified their patients' genetic risk(s) (low, moderate or high). Similarly, while confidence improved in most cases, changes in knowledge did not always alter significantly as a result of the educational intervention. This may be partly due to the difficulty in measuring changes in knowledge. Houwink et al. [29] tried to overcome this problem by using standardised patients to actually evaluate changes in practice, albeit with simulated patients. This approach would appear more valid than administration of a limited survey in which questions are often out of clinical context. Kirkpatrick's model [15] for evaluation of educational interventions stresses that assessment of the impact of the learning on patient care is an important evaluative step, but this review indicates it is one that is rarely taken. This brings us to the last methodological issue clearly emerging from this review, which shows the highest educational outcome level (level IV) [15] (organizational change and health gain, sustained change in practice behaviour and use of acquired genetics competencies), is rarely assessed in studies evaluating impact of genetics education.

Although authors of four studies assessed outcomes at Kirkpatrick's fourth level [15], they did not show clear evidence of improved impact on organizational change and health gain. One of the possible explanations could be that an increase in genetics knowledge and skills could also mean an increase in efficiency in referrals, not necessarily more or less referrals. Even if a scientific, logistical and ethical framework for the appropriate and effective use of genomic information in healthcare generally is in place, the primary care workforce is unlikely to be adequately prepared to provide such information in general practice. To do this, enhanced analysis using computer software may be helpful, but such systems must conform to regulations for preserving privacy of patients, and concerns about this aspect may be a barrier for integration of genetics and genomics in primary care [6]. As Rahimzadeh and Bartlett [6] also suggested, primary care providers may see genomics as conflicting with the holistic approach of primary care by reducing the patient to a unique molecular sequence. The same authors argue that the opportunities that genomic medicine presents for prevention and amelioration of disease fit well within the primary care 
framework and organisational change is needed to ensure that patients benefit from genomic advances.

If GPs stay genetically uneducated and therefore incompetent related to the use of genomic information in general practice, individual genetic medical care is likely to be unhelpful and may possibly be even harmful [13]. We believe the results of this review should be used in the near future to guide the implementation and level of assessment of genetics education internationally. Although the majority of the issues investigated cover genetics-related knowledge, skills and attitudes essential for every medical care provider, further studies will have to determine whether the results are relevant to other medical specialties as well.

\section{Conclusions}

From this review it can be seen that long-term impact of genetics educational initiatives on patient management and policy has been poorly assessed and there is a dearth of high quality RCTs to provide a strong evidence base for educational practice. From the existing evidence, it appears that short-term educational initiatives alone are unlikely to cause significant changes in practice in the areas of recognition of genetic risk, assessment of risk and appropriate management of patients in patient care. This may in part be due to challenges in measuring change, but perhaps changes in knowledge should not be the main aim. Rather, effecting changes in genetic awareness and the ability to find the relevant information, when needed, may be better objectives. We therefore suggest that more research is undertaken to address whether, in addition to educational programmes aiming for high impact on organizational change and health gain, sustained change in practice behaviour and use of acquired genetics competences, provision of resources to supply 'just in time' information, decision aids and other clinical tools that are accessible during the clinical encounter contribute to changing primary care practice and genetic care improvement.

\section{Additional files}

Additional file 1: Papers read in full text but not included in the review. Table of papers excluded and the reason for exclusion. (PDF $97 \mathrm{~kb}$ )

Additional file 2: Main themes and categories derived from the analysis. Table showing the main themes and all categories of data included in those themes. (PDF $26 \mathrm{~kb}$ )

\footnotetext{
Abbreviations

ELSI, ethical, legal and social issues; GP, general practitioner; OR, odds ratio; PICOS, patient population or problem, intervention (treatment/test), comparison (group or treatment), outcomes, and setting; PRISMA, preferred reporting items for systematic reviews and meta-analyses; $\mathrm{RCT}$, randomised controlled trial; SD, standard deviation; UK, United Kingdom; US, United States.

\section{Funding}

The funding for this study was provided as part of the Gen-Equip project by the Erasmus + programme. The material in this paper reflects only the authors
}

views and the European Commission and Ecorys UK are not responsible for any use that may be made of the information it contains.

Availability of data and materials

All data were extracted from published sources listed in Table 3.

\section{Authors' contributions}

HS designed the review; HS, MP and DT performed the search, quality assessment and abstraction of results. All authors contributed to writing and reviewing the manuscript. All authors read and approved the final manuscript.

\section{Competing interests}

The authors declare that they have no competing interests.

\section{Ethics approval and consent to participate}

Not applicable.

\section{Author details}

${ }^{1}$ i3S Instituto de Investigação e Inovação em Saúde, Universidade do Porto, Porto, Portugal. ${ }^{2}$ IBMC - Institute for Molecular and Cell Biology, UnIGENe and Centre for Predictive and Preventive Genetics (CGPP), Universidade do Porto, Porto, Portugal. ${ }^{3}$ Department of Medical and Surgical Sciences, Unit of Medical Genetics, University of Bologna, Bologna, Italy. ${ }^{4}$ Faculty of Health and Human Sciences, Plymouth University, Plymouth PL4 8AA, UK. ${ }^{5}$ Department of Clinical Genetics, Section Community Genetics, EMGO Institute for Health and Care Research, VU University Medical Center, Amsterdam, The Netherlands. ${ }^{6}$ Department of Family Medicine, School for Public Health and Primary Care, Maastricht University, Maastricht, The Netherlands.

Received: 14 October 2015 Accepted: 13 July 2016

Published online: 22 July 2016

\section{References}

1. Global Genes ${ }^{\mathrm{TM}}$. Rare Diseases: Facts and Statistics. 2015. Available at: Accessed 16 September 2015.

2. Rare Disease UK: 2015. Available at: [http://www.raredisease.org.uk] Accessed 6 May 2015.

3. Burke SMM, Stone A, Bennett C, Thomas H, Farndon P. Developing a curriculum statement based on clinical practice: genetics in primary care. British Journal of General Practice. 2009;59:99-103.

4. Baars MJH, Henneman L, Ten Kate LP. Deficiency of knowledge of genetics and genetic tests among general practitioners, gynecologists, and pediatricians: a global problem. Genetics In Medicine: Official Journal Of The American College Of Medical Genetics. 2005:7(9):605-10.

5. Netherlands Institute for Health Services Research (NIVEL). Living with a rare and chronic disease. 2003. http://www.nivel.nl/pdf/rare-diseases-bibliography.pdf. Accessed 10 May 2016.

6. Rahimzadeh V, Bartlett G. Genetics and primary care: where are we headed? Journal Of Translational Medicine. 2014;12:238-8.

7. World Health Organisation. Primary Health Care: Main terminology. 2016. http://www.euro.who.int/en/health-topics/Health-systems/primary-healthcare/main-terminology. Accessed 27 January 2016.

8. Acheson LS, Stange KC, Zyzanski S. Clinical genetics issues encountered by family physicians. Genetics In Medicine: Official Journal Of The American College Of Medical Genetics. 2005;7(7):501-8.

9. Houwink EJ, van Luijk SJ, Henneman L, van der Vleuten C, Jan Dinant G, Cornel MC. Genetic educational needs and the role of genetics in primary care: a focus group study with multiple perspectives. BMC Family Practice. 2011:12:5-5.

10. Houwink EJF, Henneman L, Westerneng M, et al. Prioritization of future genetics education for general practitioners: a Delphi study. Genetics In Medicine: Official Journal Of The American College Of Medical Genetics. 2012;14(3):323-9.

11. Burke S, Martyn M, Thomas H, Farndon P. The development of core learning outcomes relevant to clinical practice: identifying priority areas for genetics education for non-genetics specialist registrars. Clinical Medicine (London, England). 2009;9(1):49-52.

12. Julian-Reynier C, Nippert I, Calefato J-M, et al. Genetics in clinical practice: general practitioners' educational priorities in European countries. Genetics In Medicine: Official Journal Of The American College Of Medical Genetics. 2008;10(2):107-13. 
13. Grol R, Grimshaw J. From best evidence to best practice: effective implementation of change in patients' care. Lancet. 2003;362(9391):1225-30.

14. Weinreich SS, de Lange-de Klerk ES, Rijmen F, Cornel MC, de Kinderen M, Plass AMC. Raising awareness of carrier testing for hereditary haemoglobinopathies in high-risk ethnic groups in the Netherlands: a pilot study among the general public and primary care providers. BMC Public Health. 2009:9:338-8.

15. Kirkpatrick D. Evaluation of training. Training and Development Handbook. New York: McGraw-Hill; 1967.

16. Centre for Reviews and Dissemination. Systematic reviews. York: Centre for Reviews and Dissemination; 2009

17. Thomson Reuters. Endnote X7@. New York: US; 2016.

18. PRISMA. The Prisma Statement 2009; http://www.prisma-statement.org/ PRISMAStatement/PRISMAStatement.aspx. Accessed 10 May 2016.

19. Guttmacher AE, Collins FS. Welcome to the genomic era. New England Journal of Medicine. 2003;349(10):996-8.

20. Department of Health. Our inheritance, our future: realising the potential of genetics in the NHS. 2003. http://webarchive.nationalarchives.gov.uk/+/www dh.gov.uk/en/Publicationsandstatistics/Publications/PublicationsPolicyAnd Guidance/DH_4006538. Accessed 27 January 2016.

21. Leon AC, Davis LL, Kraemer HC. The role and interpretation of pilot studies in clinical research. Journal Of Psychiatric Research. 2011;45(5):626-9.

22. Kmet LM, Lee RC, Cook LS. Standard Quality Assessment Criteria For Evaluating Primary Research Papers From A Variety Of Fields. Canada: Alberta Heritage Foundation for Medical Research; 2004; ISBN: 1-896956-71-XX (Online).

23. Moore DE. A framework for outcomes evaluation in the continuing professional development of physicians. In: Davis DBBFR, editor. The continuing professional development of physicians: from research to practice. Chicago: American Medical Association; 2003.

24. Bethea J, Qureshi N, Drury N, Guilbert P. The impact of genetic outreach education and support to primary care on practitioner's confidence and competence in dealing with familial cancers. Community Genetics. 2008; 11(5):289-94.

25. Carroll JC, Rideout AL, Wilson BJ, et al. Genetic education for primary care providers: improving attitudes, knowledge, and confidence. Canadian Family Physician Médecin De Famille Canadien. 2009;55(12):e92-9.

26. Carroll JC, Wilson BJ, Allanson J, et al. GenetiKit: a randomized controlled trial to enhance delivery of genetics services by family physicians. Family Practice. 2011;28(6):615-23.

27. Clyman JC, Nazir F, Tarolli S, Black E, Lombardi RQ, Higgins JJ. The impact of a genetics education program on physicians' knowledge and genetic counseling referral patterns. Medical Teacher. 2007;29(6):e143-50.

28. Emery J, Morris H, Goodchild R, et al. The GRAIDS Trial: a cluster randomised controlled trial of computer decision support for the management of familial cancer risk in primary care. British Journal Of Cancer. 2007:97(4):486-93.

29. Houwink EJF, Muijtjens AMM, van Teeffelen SR, et al. Effectiveness of oncogenetics training on general practitioners' consultation skills: a randomized controlled trial. Genetics In Medicine: Official Journal Of The American College Of Medical Genetics. 2014;16(1):45-52.

30. Houwink EJF. Sustained effects of online genetics education: a randomized controlled trial on oncogenetics. European Journal of Human Genetics. 2014;22:310-6.

31. Laberge A-M, Fryer-Edwards K, Kyler P, Lloyd-Puryear MA, Burke W. Long-term outcomes of the "Genetics in Primary Care" faculty development initiative. Family Medicine. 2009;41(4):266-70.

32. Metcalfe $S$, Seipolt $M$, Aitken $M$, Flouris A. Educating general practitioners about prenatal testing: approaches and challenges. Prenatal Diagnosis. 2005; 25(7):592-601.

33. Srinivasan J, Rowett E, Dharni N, Bhatt H, Day M, Chu CE. Improving access to cancer genetics services in primary care: socio-economic data from North Kirklees. Familial Cancer. 2007;6(2):197-203.

34. Wilson BJ, Torrance N, Mollison J, et al. Cluster randomized trial of a multifaceted primary care decision-support intervention for inherited breast cancer risk. Family Practice. 2006;23(5):537-44.

35. Wilson BJ, Torrance N, Mollison J, et al. Improving the referral process for familial breast cancer genetic counselling: findings of three randomised controlled trials of two interventions. Health Technology Assessment (Winchester, England). 2005;9(3):iii.

36. Thomson O'Brien MA, Oxman AD, Davis DA, et al. Educational outreach visits: effects on professional practice and health care outcomes (Cochrane Review). In: The Cochrane Library, Issue 1, 2000. Oxford: Update Software.
37. Davis DA, Thomson MA, Oxman AD, Haynes RB. Changing physician performance. A systematic review of the effect of continuing medical education strategies. JAMA. 1995;274:700-5.

38. Kern DE, Thomas PA, Howard DM, Bass EB. Curriculum Development for Medical Education: A Six-Step Approach. Baltimore, Md: Johns Hopkins University Press; 1998.

39. Trinidad SB, Fryer-Edwards K, Crest A, Kyler P, Lloyd-Puryear MA, Burke W. Educational needs in genetic medicine: primary care perspectives. Community Genetics. 2008;11(3):160-5.

40. Adam C. Berger, Samuel G. Johnson, Sarah HB, Steve O, Institute of Medicine of the National Academies. Improving Genetics Education in Graduate and Continuing Health Professional Education: Workshop Summary. Washington: The National Academies Press; 2015. www.nap.edu.

41. Rinke ML, Mikat-Stevens N, Saul R, Driscoll A, Healy J, Tarini BA. Genetic services and attitudes in primary care pediatrics. American Journal Of Medical Genetics Part A. 2014;164A(2):449-55.

42. Burke W, Acheson L, Botkin J, et al. Genetics in primary care: a USA faculty development initiative. Community Genetics. 2002;5(2):138-46.

\section{Submit your next manuscript to BioMed Central and we will help you at every step:}

- We accept pre-submission inquiries

- Our selector tool helps you to find the most relevant journal

- We provide round the clock customer support

- Convenient online submission

- Thorough peer review

- Inclusion in PubMed and all major indexing services

- Maximum visibility for your research

Submit your manuscript at www.biomedcentral.com/submit

) Biomed Central 